\title{
A TEORIA DO DOMÍNIO DO FATO E O CÓDIGO PENAL BRASILEIRO
}

THE THEORY OF THE FACT'S DOMAIN AND THE BRAZILIAN CRIMINAL CODE

Paulo César Busato ${ }^{1}$ Universidade Federal do Paraná

Rodrigo Cavagnari ${ }^{2}$ FAE Centro Universitário/ PR

\section{Resumo}

O presente trabalho debate a legitimidade de aplicação da teoria do domínio do fato no conjunto de regras assistemático do Código Penal brasileiro - referente ao título do concurso de pessoas - analisando-a à margem do sectarismo dos sistemas unitário e diferenciador.

\section{Palavras-chave}

Concurso de pessoas. Código Penal brasileiro. Teoria do domínio do fato.

\section{Abstract}

The present work debate the legitimacy of applying the fact's domain theory in the no sistemic rules of the Brazilian Penal Code - about the cooperation title analyzing the case beyond the sectarianism of the unitary and differentiator systems.

\section{Keywords}

Cooperation. Brazilian Penal Code. Fact's domain theory.

\footnotetext{
${ }^{1}$ Professor de Direito Penal (UFPR e FAE Centro Universitário), Pós-Doutor em Direito penal pela Universidad de Valencia, Espanha, Procurador de Justiça do Ministério Público do Estado do Paraná.

2 Professor de Direito Penal (FAE Centro Universitário - Law Experience, PR).
} 


\section{INTRODUÇÃO}

Pretende-se nesse trabalho desenhar uma proposta de interpretação do assistemático conjunto de normas do Código Penal brasileiro que regula a autoria e participação. Para tanto, visa-se utilizar os critérios diferenciadores propostos pela teoria do domínio do fato, ainda que tenham sido tais critérios elaborados tendo por foco uma teoria diferenciadora e um grupo limitado de delitos. Não se trata de pretender uma simples aplicação de uma teoria desenhada para uma legislação em outra ou para um sistema em outro, até porque, um tal propósito estaria $a b$ initio destinado ao fracasso. Trata-se, isso sim, de demonstrar que alguns critérios empregados pelo desenvolvimento do tema nos moldes oferecidos por Roxin, podem ser utilizados como filtros axiológicos de delimitação do alcance da responsabilidade penal no concurso eventual de pessoas proposto pelo Código Penal brasileiro.

O tema do concurso de pessoas é absolutamente relevante, pois ele integra a teoria do crime. Ainda que seja usual situar o concurso de pessoas no final da apresentação da estrutura da teoria do delito, isto se dá não por uma redução de importância do tema, mas sim por uma questão didática, já que o conhecimento de todos os elementos do crime resulta importante para a exploração dos critérios de unidade concursal. Isso não torna o ponto menor ou menos importante e o desenvolvimento teórico nesta área mostra bem isso.

De outro lado, tal desenvolvimento teórico, no momento da conjunção com o sistema normativo brasileiro tem causado imensos problemas, especialmente por força de importação teórica acrítica.

Isto fica especialmente evidente nos intentos forenses de emprego da chamada teoria do domínio do fato. 
A doutrina especializada tem se debruçado sobre o tema mostrando as incongruências da aplicação de tal teoria em face do conjunto normativo brasileiro que regula o tema do concurso de pessoas. Usualmente, as conclusões das vozes mais respeitáveis no tema, culminam por uma crítica ao legislador brasileiro, que não pode ser menos que correta.

Exige-se, porém, uma abordagem prática.

É preciso ter em conta que o sistema normativo existe e é aplicado cotidianamente.

Assim, o exercício que aqui propomos é o de verificar a utilidade dos critérios teóricos desenvolvidos no plano da teoria do domínio do fato para a solução de problemas práticos de concurso de pessoas, em face do conjunto de normas que regulam o tema no Código Penal brasileiro.

\section{O CÓDIGO PENAL BRASILEIRO ADOTA UMA TEORIA UNITÁRIA?}

Parte da doutrina nacional ${ }^{3}$ afirma, peremptoriamente, que o Código Penal brasileiro, tanto em 1940 quanto na reforma de 1984, adotou a teoria unitária para disciplinar o concurso de pessoas.

Para BITENCOURT, a teoria unitária foi adotada pelo Código

Cf.: BITENCOURT, Cezar Roberto. Tratado de Direito Penal, Parte Geral. Vol. 1. 14 ed. São Paulo: Saraiva, 2009; BRANDÃO, Cláudio. Curso de Direito Penal, Parte Geral. Rio de Janeiro: Forense, 2008; DOTTI, René Ariel.

Apresentação. In: LEITE, Alaor. Domínio do fato ou domínio da posição?: autoria e participação no direito penal brasileiro. Curitiba: Centro de Estudos Professor Dotti, 2016; FRAGOSO, Heleno Cláudio. Lições de Direito Penal, Parte Geral. 15 ed. Rio de Janeiro: Forense, 1995; MESTIERI, João. Manual de Direito Penal, Parte Geral. Vol. I. Rio de Janeiro: Forense, 2002, pp. 199-200. 
Penal de 1940 e a reforma de 1984 manteve a escolha dessa teoria ${ }^{4}$. Assinala o autor que, na reforma, procurou-se atenuar os rigores da teoria unitária, distinguindo-se, com precisão, a punibilidade da autoria e da participação ${ }^{5}$. Ademais, foram estabelecidos alguns princípios disciplinando determinados graus de participação ${ }^{6}$. Conclui dizendo que foi adotada como regra a teoria monística, determinando que todos os participantes de uma infração penal incidem nas sanções de um único e mesmo crime e, como exceção, a concepção dualista, mitigada, distinguindo a atuação de autores e partícipes, permitindo a adequada dosagem de pena de acordo com a eficácia causal da conduta de cada partícipe, na medida da culpabilidade perfeitamente individualizada ${ }^{7}$.

BRANDÃO assinala que o Código Penal brasileiro adotou as linhas gerais da teoria monista, conforme se depreende do caput do art. 298. Tal teoria apregoa a unicidade de crime em face da pluralidade de agentes, logo, tanto os autores quanto os partícipes responderão por um único crime, afastando-se tanto a ideia de fracionamento da conduta delituosa quanto a ideia de bipartição da conduta criminosa ${ }^{9}$. Acrescenta BRANDÃO que o fundamento dessa teoria reside no fato de as várias ações não se apresentarem de um modo autônomo, mas convergirem em uma operação única, que acarretam um mesmo resultado, por isso, elas devem ser consideradas como um todo unitário $^{10}$. Aduz, ainda, quando a lei estabelece que, qualquer que seja

BITENCOURT, Cezar Roberto. Tratado de Direito Penal...cit., p. 446.

5 Idem, p. 446.

6 Idem, p. 446.

7 Idem, pp. 446-447.

$8 \quad$ BRANDÃO, Cláudio. Curso de Direito Penal...cit., p. 269.

9 Idem, p. 269.

$10 \quad$ Idem, p. 269. 
a forma de concorrer para o delito, o sujeito incide nas penas ao mesmo cominadas, ela prevê que a contribuição do agente para o crime independentemente de seu grau - acarretará a sua responsabilidade penal, o qual será tido como sujeito ativo do delito ${ }^{11}$. Ressalta o autor que, hodiernamente, a teoria monista importa na unicidade de crime, mas não na unicidade de pena ${ }^{12}$.

Segundo DOTTI, o sistema unitário foi adotado na redação do art. 25 da velha Parte Geral do Código Penal (1940) e repetido no caput do art. 29 da reforma de $1984^{13}$. Parte-se do princípio de que não haverá mais diferença entre participação principal e participação acessória, entre auxílio necessário e auxílio secundário, entre a societas criminis e a societas in crimine ${ }^{14}$. Assim, quem emprega qualquer atividade para a realização do evento criminoso é considerado responsável pela totalidade ele, no pressuposto de que também as outras forças concorrentes entraram no âmbito da sua consciência e vontade ${ }^{15}$.

Sem dúvida, esta é uma opção político criminal mais interventiva, de ampliação do espectro de responsabilização penal, o que não é de estranhar, sabendo, como anotou, em seu momento, FRAGOSO, que a opção foi inspirada no exemplo do Código Penal italiano $^{16}$. A escolha vincula-se à teoria da equivalência dos

Idem, p. 269.

12 Idem, p. 269.

13 DOTTI, René Ariel. Apresentação...cit., p. 12.

14 DOTTI, René Ariel. Apresentação. In: LEITE, Alaor. Domínio do fato ou domínio da posição?: autoria e participação no direito penal brasileiro. Curitiba: Centro de Estudos Professor Dotti, 2016, p. 12.

FRAGOSO, Heleno Cláudio. Lições de Direito Penal...cit., p. 251. 
antecedentes, adotada quanto à relação de causalidade ${ }^{17}$. Assim, como não se distingue entre os vários antecedentes causais do delito, não se distingue também entre os vários partícipes na empresa delituosa comum: todos são coautores e responderão pelo crime segundo a mesma escala penal ${ }^{18}$. Somente se distingue entre os diversos partícipes na aplicação da pena, que dependerá da culpabilidade maior ou menor de cada um ${ }^{19}$.

Como bem anotou MESTIERI, tal opção não apenas afasta a distinção entre participação principal e acessória, entre autores e cúmplices, como também dilui qualquer diferenciação entre participação moral e material ${ }^{20}$. Outrossim, ressalta o autor, que seria mais correto falar que o legislador adotou uma teoria unitária temperada, pois o instituto do concurso de pessoas está subordinado à teoria da culpabilidade, e, com isso, distingue-se, ainda que tacitamente, entre autoria e participação, além de limitar a punição à contribuição pessoal de cada protagonista ${ }^{21}$, quando se impôs, no final no caput do art. 29 e em seus parágrafos, distinções entre aqueles que concorrem para o delito.

\subsection{O QUE É UMA TEORIA UNITÁRIA?}

A teoria unitária, em sua formulação clássica, assenta-se na premissa de que todo aquele que contribui causalmente para o crime é

Idem, p. 251. Também MESTIERI, João. Manual de Direito Penal...cit., p. 200.

FRAGOSO, Heleno Cláudio. Lições de Direito Penal...cit., p. 251.

19 Idem, p. 251.

20 MESTIERI, João. Manual de Direito Penal...cit., p. 199.

21 Idem, p. 200. 
autor ou concorrente ${ }^{22}$. As diferenças evidentes no grau de participação de cada um serão levadas em consideração pelo juiz do caso no momento de aplicação da pena ${ }^{23}$. A distinção entre as formas de contribuição é, pois, de natureza meramente quantitativa ${ }^{24}$.

Um sistema unitário não diferencia autor de partícipe ou o faz apenas no plano conceitual, fixando o mesmo marco penal para todos os que concorrem para o fato ${ }^{25}$. Em tal sistema, a forma e a intensidade da contribuição de cada concorrente são relevantes apenas para aplicação da pena ${ }^{26}$.

Assim, o sistema unitário é aquele que (i) iguala todas as contribuições causais para o delito e prevê marcos penais idênticos para todas (unitário formal); ou, (ii) que distingue no plano conceitual entre várias formas de contribuição, mas continua a prever os mesmos marcos penais para as diferentes formas de intervenção ${ }^{27}$.

Para a teoria unitária, o crime praticado por distintas pessoas em conjunto não deixa de ser uno. Portanto, tanto autores quanto partícipes respondem pelo mesmo crime. Não se distingue entre autor,

22 LEITE, Alaor. Domínio do fato ou domínio da posição?: autoria e participação no direito penal brasileiro. Curitiba: Centro de Estudos Professor Dotti, 2016, p. 34.

$23 \quad$ Idem, p. 34.

$24 \quad$ Idem, p. 34.

25 GRECO, Luis, TEIXEIRA, Adriano. Autoria como realização do tipo: uma introdução à ideia de domínio do fato como o fundamento central da autoria no Direito penal brasileiro. In: GRECO, Luís (et alii) Autoria como domínio do fato: estudos introdutórios sobre o concurso de pessoas no direito penal brasileiro. São Paulo: Marcial Pons, 2014, p. 51.

$26 \quad$ Idem, p. 51.

27 GRECO, Luís (et alii) Autoria como domínio do fato: estudos introdutórios sobre o concurso de pessoas no direito penal brasileiro. São Paulo: Marcial Pons, 2014, p. 13. 
partícipe, instigador, cúmplice etc., sendo todos coautores do crime. A dificuldade aqui é que quem empresta a arma tem a pena fixada a partir do mesmo marco do homicida, quem indica a casa vazia teria a pena fixada a partir do mesmo marco do ladrão ${ }^{28}$. Em princípio, aquele que aperta o gatilho, mas também aquele que empresta a arma ou grita "mate", poderiam ser tratados como homicidas 29.

\subsection{O QUE É UMA TEORIA DIFERENCIADORA?}

O sistema diferenciador distingue várias formas de intervenção do delito, isto é, distingue entre autores e partícipes, e pode prever, ademais, diferentes marcos penais para as diferentes formas de intervenção ${ }^{30}$. Para LEITE, a teoria diferenciadora assenta-se na premissa de que já no plano do tipo há uma distinção qualitativa entre autores e partícipes ${ }^{31}$.

Como bem refere MUÑOZ CONDE, a participação é essencialmente menos grave que a autoria, existindo entre elas uma diferenciação inclusive conceitual ${ }^{32}$.

Como já sustentado em outro trabalho, repisa-se que o sistema diferenciador cinge-se à forma de repartição da responsabilidade dos diversos concorrentes de modo desigual, considerando as diferentes contribuições para o ilícito, que podem derivar da teoria pluralista ou

BUSATO, Paulo César. Direito Penal, Parte Geral. 3 ed. São Paulo: Atlas, 2017, p. 671.

29 LEITE, Alaor. Domínio do fato ou domínio da posição?...cit., p. 34.

30 GRECO, Luís (et alii) Autoria como domínio do fato...cit., p. 13.

31 LEITE, Alaor. Domínio do fato ou domínio da posição?...cit., p. 34.

32 MUÑOZ CONDE, Francisco, GARCÍA ARÁN, Mercedes. Derecho Penal, Parte General. 5 ed. Valencia: Tirant lo Blanch, 2002, p. 446. 
da teoria dualista ${ }^{33}$.

A teoria pluralista entende que o concurso eventual de pessoas é meramente uma construção jurídica, porque na realidade a multiplicidade de agentes corresponde a uma multiplicidade de crimes. Cada agente deveria responder pela sua própria conduta, de modo diferenciado, pelo que se trata de vários crimes praticados em concurso. A multiplicidade de agentes corresponde a um concurso real de ações distintas. Haveria uma pluralidade de delitos, cada agente praticando um delito que lhe é próprio. Critica-se essa teoria porque o tipo realizado é um só e as participações dos agentes convergem para uma ação única, com um único resultado. É muito difícil conceber, por exemplo, que se um agente aponta a arma para uma vítima enquanto o outro subtrai a carteira desta não devam ser ambos responsáveis por roubo, mas sim um por ameaça e outro por furto ${ }^{34}$.

A teoria dualista sustenta que nos crimes onde existe concurso eventual de pessoas, os autores (principais) deverão responder conjuntamente por um delito, enquanto que os partícipes (acessórios) deverão responder conjuntamente por outro. Ou seja, haveria uma bipartição do delito entre autores e partícipes. Existiria uma ação principal, do autor do crime ou dos coautores, que executam a ação típica e as ações acessórias, levadas a cabo pelas pessoas que induzem, instigam ou auxiliam o autor ou os autores a cometerem o ilícito ${ }^{35}$.

O problema aqui aparece quando a ação do eventual partícipe, que figuraria como auxiliar ou instigador, é mais importante que a conduta de quem executa o núcleo do tipo. Por exemplo, quem contrata alguém para surrar um terceiro. Ademais, do mesmo modo

BUSATO, Paulo César. Direito Penal, Parte Geral...cit., p. 670. 
que com a teoria pluralista, o evento continua sendo um só, e não dois $^{36}$.

Além disso, em uma teoria dualista, seria preciso estabelecer, mediante juízos de valor, o que define um autor e um partícipe, ingressando, aqui, a conhecida multiplicidade de teorias ${ }^{37}$ que visam obter tal definição, as quais didaticamente costumam ser agrupadas em teorias subjetivas ${ }^{38}$, objetivo-formais ${ }^{39}$ e objetivo-materiais ${ }^{40}$.

$36 \quad$ Idem, pp. 670-671.
$37 \quad$ A essas distinções também referem, por exemplo: BITENCOURT, Tratado de Direito Penal...cit., 449-451; GALVÃO, Fernando. Direito Penal, Parte Geral. 5 ed. São Paulo: Saraiva, 2013, pp. 509-513; SANTOS, Juarez Cirino dos. Direito Penal, Parte Geral. 3 ed. Curitiba: ICPC/Lumen Juris, 2008, pp. 357-361. 38 Para a teoria subjetiva, o que define o autor, o que o diferencia do partícipe, é que o autor quer o fato como seu, ou seja, manifesta subjetivamente uma intenção de realizar o crime. O partícipe teria apenas um ânimo associativo, ou seja, manifestaria uma intenção de participar de crime como fato de outro. Existe coautoria, na medida em que ambos querem o fato como seu. O partícipe seria aquele que contribui com o fato, porém o quer como fato alheio (cf. BUSATO, Paulo César. Direito Penal...cit., p. 673).

39 Para a teoria objetivo formal, autor é aquele que realiza o núcleo do tipo, ou seja, a ação expressa pelo verbo contido no tipo. Assim, o autor é quem realiza, por exemplo, a ação de matar no homicídio e de subtrair no furto. O partícipe realiza outras ações que, conquanto sejam contributivas para a obtenção do resultado, não configuram o núcleo do tipo. Nos casos de coautoria, explica-se a divisão de tarefas sob a forma de coautoria executiva direita e coautoria executiva parcial. A coautoria executiva direta seria quando os coautores dividem diretamente a realização completa do delito. No caso da coautoria executiva parcial, os coautores repartem tarefas (cf. BUSATO, Paulo César. Direito Penal...cit., p. 675).

40 Para a teoria objetivo-material, considera-se a maior perigosidade que deve caracterizar a contribuição do autor em comparação com a do partícipe, em outras palavras, considerando a maior importância objetiva da contribuição do 


\subsection{A CRÍTICA: É IMPOSSÍVEL FALAR DE UMA TEORIA MISTA.}

Assinala LEITE, que não existe uma teoria mista ou, como já defendido em nossa doutrina, um sistema unitário temperado ou um sistema unitário que faz concessões ao sistema diferenciador. Acrescenta o autor: "um tal sistema misto - que acende uma vela a deus, outra ao diabo - não mereceria o nome de sistema" ${ }^{\text {"ł1 }}$.

Com efeito, tomada a ideia kantiana de sistema, não é possível pensar que um sistema que pretenda resolver a questão do concurso de pessoas possa ser ao mesmo tempo unitário e diferenciador, já que estas são propostas mutuamente excludentes. Afinal, KANT entendia por sistema "a unidade dos diversos conhecimentos dentro de uma ideia" ${ }^{42}$.

No entanto, é preciso ter em mente o que pretendia KANT, com seu sistema. Ele deixou claro que "a unidade sistemática é o que converte o conhecimento comum em ciência"43, pois através de tal unidade, se obtinha as características científicas de completude, unidade e correção.

Porém, é preciso cuidar-se quanto a esta pretensão de ciência, quando se trata do direito, especialmente do Direito penal.

É questionável que se possa falar em ciência penal, pois como adverte Vives Antón, "o delito não é um objeto real, e, por conseguinte, à estrutura do sistema não corresponde a nenhuma estrutura objetiva. E a dogmática não é nenhuma classe de ciência, mas

autor em relação à contribuição do partícipe (cf. BITENCOURT, Tratado de Direito Penal...cit., pp. 450-451).

41 LEITE, Alaor. Domínio do fato ou domínio da posição?...cit., p. 35.

$42 \quad$ KANT, Immanuel. Crítica da razão pura. $3^{\mathrm{a}}$ ed., Trad. Lucimar A. Coghi Anselmi, São Paulo: Ícone, 2011, p. 522.

Idem, p. 521. 
só uma forma de argumentar ao redor de uns tópicos que não são senão determinações do que entendemos por ação e do que entendemos por norma, e do processo em virtude do qual podemos julgar as ações desde as normas jurídicas e desde os valores aos quais as normas jurídicas servem de veículo"ł.

Portanto, a questão de um sistema científico não pode ser a preocupação última do jurista penal, senão que, figura muito antes a preocupação com a forma de levar a cabo a conjunção entre normas e condutas.

\subsection{COMO CHAMAR O CONJUNTO NORMATIVO DO CP/84?}

Parece bastante óbvio que a opção inicial do legislador em partir de uma regra geral unitária apareceu pela pretensão de dotar o todo do Código de uma fórmula coerente. Uma opção pelo sistema unitário responderia melhor à ideia de causa, segundo a teoria dos equivalência dos antecedentes ${ }^{45}$, que era adotada no Código.

O que há de bom nesta perspectiva é esta congruência para com a adoção da ideia de causalidade natural como fonte da imputação do resultado, já que o Código não contemplava critérios legais axiológicos que funcionassem como filtros auxiliares da imputação objetiva. Ademais, convém lembrar que as demais teorias da causalidade, seja causalidade adequada, causalidade relevante, etc., jamais ofereceram níveis aceitáveis e universais de segurança jurídica e sua adoção mesmo que implícita - não melhoraria o sistema de imputação.

De outro lado, sempre foi claro que um sistema unitário pode

$44 \quad$ VIVES ANTÓN, Tomás S. Fundamentos del Sistema penal. 2a ed., Valencia: Tirant lo Blanch, 2011, p. 489.

$45 \quad$ BUSATO, Paulo César. Direito Penal...cit., p. 671. 
levar a uma ampliação desmedida da carga penal, caso tomado em termos absolutos.

E é exatamente por isso que o legislador brasileiro optou por acrescentar à base unitária, regras que implicam na diferenciação obrigatória entre os perpetradores de um delito em concurso eventual.

Esta motivação resta absolutamente clara e explicitamente explicada na exposição de motivos da então "nova" Parte Geral, em seu item 25. Diz-se: "[...JO Código de 1940 rompeu a tradição originária do Código Criminal do Império, e adotou neste particular a teoria unitária ou monística do Código italiano, como corolário da teoria da equivalência das causas (Exposição de Motivos do Ministro Francisco Campos, item 22). Em completo retorno à experiência passada, curvase, contudo, o Projeto, aos critérios dessa teoria, ao optar, na parte final do artigo 29, e em seus dois parágrafos, por regras precisas que distinguem a autoria de participação. Distinção, aliás, reclamada com eloqüência pela doutrina, em face de decisões reconhecidamente injustas".

Partindo-se de que existem, reconhecidamente, dois sistemas (se são, de fato, sistemas): um unitário, outro diferenciador, seria o nosso código penal assistemático? Como já visto acima, no unitário todo mundo que contribui para o crime responde pelo crime. No diferenciador, concorre para o crime como autores uns e como partícipes outros (define que há concorrências diferentes; um principal e outro acessório).

De fato, como salienta LEITE, o Código Penal brasileiro simplesmente não adotou um sistema uno e coerente de autoria e participação. Ao menos, não fez a opção entre um dos dois sistemas já então consagrados e estabelecidos em termos de regras gerais. Não há, por assim dizer, decisão convicta do legislador em favor do sistema 
unitário ${ }^{46}$. A exposição de motivos diz que parte do conceito unitário. Mas, também, diz que, no entanto, cada um responde na medida da culpabilidade (grau de reprovabilidade). A nova parte geral introduziu $\S 1$ e $\S 2$ obrigando a diferenciar a condição daquele cuja participação no delito foi de menor importância, bem como aquele que quis participar de crime diverso do perpetrado.

O Código Penal brasileiro, em obediência à adoção do conceito de causa próprio da teoria da equivalência dos antecedentes, logicamente, caminhou para a adoção de uma teoria unitária do concurso eventual de pessoas, admitindo que todas as contribuições para uma prática delitiva geram responsabilidade por ela. Entretanto, igualmente se adiantou em reconhecer a pertinência de certas críticas à referida teoria, promovendo matizações à ideia de igualdade absoluta das contribuições para o crime e o fez mediante a adição de regras obrigando a diferenciar certas participações.

As questões que se põem, então, são: i) Ainda que exista, no plano teórico, um conjunto de regras clássicas que conformam um sistema diferenciador, oposto direto de um conjunto de regras consagradas, que conformam um sistema unitário, o que realmente define um sistema? ii) A coerência entre as regras que compõem um conjunto normativo deve ser estabelecida entre as próprias normas que o compõem ou para com teorias e conceitos pré-existentes externos ao conjunto normativo? Como deve ser chamado um conjunto normativo que estabelece regras que obrigam a partir de um marco típico único e a diferenciar a carga de sanção entre aqueles que contribuem para a prática de tal delito, definindo uma obrigatoriedade de redução em face de contribuições menos importantes?

Estas - e não quaisquer outras - são as perguntas que cabe 
responde.

Fazendo a pergunta errada, jamais chegaremos à resposta certa.

É absolutamente inútil discutir se o Código Penal brasileiro adota a teoria $\mathrm{A}$ ou a teoria $\mathrm{B}$ a respeito do concurso de pessoas, ou como se chama esta ou aquela teoria, ou quando se deve chamar um sistema por este ou aquele nome, ou até mesmo quando se pode chamar um conjunto normativo de sistema. A questão a ser respondida é, antes, de praxis forense: diante de um caso de concurso eventual de pessoas, à luz do conjunto de normas do Código Penal brasileiro, deve o juiz distinguir entre as contribuições principais e acessórias? Neste sentido, parece inafastável uma conclusão positiva. Desta resposta deriva outra pergunta: esta distinção deve operar-se levando em conta quais critérios diferenciadores?

Isto é o que realmente importa acerca do concurso de pessoas.

Visto por este prisma, ao final, é forçoso concluir que o sistema (se é que existe) ou a teoria (se pode ser assim chamada) adotados são mesmo diferenciadores ${ }^{47}$, quer chamemos isso de teoria, quer chamemos de sistema, ou simplesmente digamos que se fez uma "opção diferenciadora".

Como visto, o Código Penal brasileiro adota, na verdade, um perfil diferenciador em sentido dualista. O princípio é unitário, porém, expressamente se reconhece a necessidade de matizações e bipartições que obrigam a considerar a hipótese de necessária diferenciação entre autores e partícipes ${ }^{48}$.

Ademais, o Código ainda mantém, na parte especial (que é de 1940), situações de exceção pluralística ao princípio unitário do concurso de pessoas, o que deixa evidente que já mesmo antes da 
reforma de 1984 existia uma tendência a minimizar o absolutismo monista. Exemplos disso são as hipóteses (i) de aborto, onde a mesma situação de fato pode levar à punição do médico que realiza o aborto e da gestante que o consente em tipos penais diferentes; e, (ii) de corrupção, onde o único fato de que um particular entrega a um policial uma quantia em dinheiro para que aquele não lavre uma multa de trânsito contra ele conduz à punibilidade do particular e do policial por tipos penais diferentes ${ }^{49}$.

Desse modo, segundo o Código Penal brasileiro, comete homicídio quem mata alguém mediante disparos e partícipe quem empresta a arma àquele que disparou. Comete furto quem invade a residência, subtraindo, de lá, para si, os eletrodomésticos e jóias, e aquele que indicou a casa que estaria vazia para ser assaltada ${ }^{50}$, porém, entre eles, existe necessidade clara e determinada na própria lei de diferenciar entre autores (principais) e partícipes (acessórios).

É claro que a distinção entre autor e partícipe não basta e nem é a última etapa da divisão de responsabilidades e consequentemente de cargas penais. A operação de atribuição de pena é complexa e pode levar a uma profunda elevação da pena de um partícipe e também à relevante redução da pena de um autor. A diferenciação aqui visa, simplesmente, estabelecer uma relação de subordinação e de essencialidade-acessoriedade entre autores e partícipes ${ }^{51}$.

De qualquer modo, uma vez concluído pela necessidade de diferenciação entre autor e partícipe, da opção por uma perspectiva diferenciadora surge o segundo problema, que é o critério pelo qual há que se distinguir a figura do autor e do partícipe ${ }^{52}$.

$\begin{array}{ll}49 & \text { Idem, p. } 672 . \\ 50 & \text { Idem, p. } 679 . \\ 51 & \text { Idem, p. } 672 . \\ 52 & \text { Idem, pp. 672-673. }\end{array}$


Embora tenham surgido várias teorias que visaram explicar o motivo pelo qual a atuação de uma pessoa pode ser principal em relação à atuação de outra, dentre elas a teoria subjetiva, a teoria objetivo-formal e a teoria do domínio do fato ${ }^{53}$, o presente trabalho cingirá à exposição da última, que representa um dos pontos do debate.

\section{A TEORIA DO DOMÍNIO DO FATO}

Em face da insuficiência do critério objetivo-formal para responder a situações mais complexa de relações de grupos criminosos, a doutrina buscou um critério objetivo-material de identificação do autor. Importa aqui mais do que simplesmente a realização do núcleo do tipo, mas sim o efetivo (material) domínio da realização do delito ${ }^{54}$.

\subsection{ANTECEDENTES NOMINAIS}

As expressões domínio do fato e domínio sobre o fato foram empregadas pela primeira vez no Direito Penal no ano de 1915, por HEGLER $^{55}$. O domínio do fato integral, na expressão de HEGLER, era analisado como pressuposto material da culpabilidade, ou seja, para ele somente agia com culpabilidade quem tinha o domínio do fato ${ }^{56}$. Mas tarde, o próprio HEGLER procurou transferi-lo à teoria da autoria, para afirmar que o autor livre e capaz de imputação era o senhor sobre

\footnotetext{
$53 \quad$ Idem, p. 673.

$54 \quad$ Idem, p. 676.

55 ROXIN, Claus. Autoría y dominio del hecho en Derecho penal. Trad.

Joaquín Cuello Contreras e José Luis Serrano González de Murillo. Madrid: Marcial Pons, 2000, p. 81; SILVA, Pablo Rodrigo Alflen da. Teoria do domínio do fato. São Paulo: Saraiva, 2014, p. 82.

SILVA, Pablo Rodrigo Alflen da. Teoria do domínio do fato...cit., p. 83.
} 
o fato em sua condição inerente; faltando ao instrumento a capacidade de imputação (culpabilidade), faltaria também o domínio do fato ${ }^{57}$. Acentue-se que ainda não possuía a conotação que se lhe empresta atualmente, estando mais atreladas aos fundamentos da culpabilidade ${ }^{58}$.

Em 1932, BRUNS utilizou a expressão domínio do fato para delimitar pela primeira vez autoria e participação $0^{59}$. Para BRUNS, a autoria pressupõe, ao menos, a possibilidade de domínio do fato que, inclusive, deve ser inerente à conduta desde o princípio, de modo que o domínio do fato existe somente quando uma conduta em geral é adequada para causar o resultado ${ }^{60}$. Ademais, na instigação e no auxílio falta o domínio do fato em relação ao resultado final ${ }^{61}$.

Três anos depois de BRUNS, foi VON WEBER ${ }^{62}$ quem voltou a utilizar a expressão domínio do fato para justificar o emprego da teoria subjetiva na delimitação do conceito de autoria e consequente distinção da participação. Ele transporta a expressão domínio do fato -

$57 \quad$ Idem, p. 83.

$58 \quad$ ROXIN, Claus. Autoría y dominio del hecho en Derecho penal...cit., p. 81; GRECO, Luís, LEITE, Alaor. O que é e o que não é a teoria do domínio do fato. Sobre a distinção entre autor e participe no Direito penal. In: GRECO, Luís (et alii) Autoria como domínio do fato: estudos introdutórios sobre o concurso de pessoas no direito penal brasileiro. São Paulo: Marcial Pons, 2014, p. 21.

$59 \quad$ ROXIN, Claus. Autoría y dominio del hecho en Derecho penal...cit., p. 82; SILVA, Pablo Rodrigo Alflen da. Teoria do domínio do fato...cit., pp. 83-84.

60 SILVA, Pablo Rodrigo Alflen da. Teoria do domínio do fato...cit., p. 84.

$61 \quad$ ROXIN, Claus. Autoría y dominio del hecho en Derecho penal...cit., p. 83; SILVA, Pablo Rodrigo Alflen da. Teoria do domínio do fato...cit., p. 84.

62 Veja-se o desenvolvimento completo da distinção em WEBER, Hellmuth von. Lineamientos del Derecho penal alemán. Trad. de Leonardo G. Brond, Buenos Aires: Ediar, 2008, pp. 68-76. Veja-se comentários a respeito em ROXIN, Claus. Autoría y dominio del hecho en Derecho penal...cit., p. 84; SILVA, Pablo Rodrigo Alflen da. Teoria do domínio do fato...cit., p. 85. 
até então compreendida de maneira objetiva - ao âmbito subjetivo, referindo ser autor quem pratica o fato com vontade própria de dominá-1o ${ }^{63}$.

Particular importância teve LOBE, pois, pela primeira vez, apresentou um conceito de domínio do fato no plano da autoria ${ }^{64}$, considerando que a autoria determina-se de acordo com elementos objetivos e subjetivos, a saber, o querer o resultado, o domínio e a condução fática da execução, o animus domini e o respectivo dominar realmente a execução ${ }^{65}$.

\subsection{WELZEL}

Para além das especulações desenvolvidas até então, WELZEL procurou elaborar pela primeira vez uma teoria propriamente dita do domínio do fato, que fosse orientada por critérios bem definidos e que servisse de diretriz para o desenvolvimento ulterior da teoria da autoria e da participação ${ }^{66}$.

Com isso, em 1939, WELZEL apresentou sua concepção de domínio do fato, vinculando-a ao seu conceito de ação final ${ }^{67}$. Para ele, a vontade e a realização da vontade integrariam a própria ação, a vontade de cometer o fato como próprio restaria por ser elevada a

63 SILVA, Pablo Rodrigo Alflen da. Teoria do domínio do fato...cit., p. 85. 64 GRECO, Luís, LEITE, Alaor. O que é e o que não é a teoria do domínio do fato...cit., p. 21.

65 ROXIN, Claus. Autoría y dominio del hecho en Derecho penal...cit., pp. 84-85; SILVA, Pablo Rodrigo Alflen da. Teoria do domínio do fato...cit., p. 85.

66 WELZEL, Hans. Derecho Penal Alemán. 4 ed. Trad. Juan Bustos Ramírez e Sérgio Yáñez Pérez. Santiago: Editorial Jurídica de Chile, 1997, p. 120; SILVA, Pablo Rodrigo Alflen da. Teoria do domínio do fato...cit., pp. 86-87.

67 ROXIN, Claus. Autoría y dominio del hecho en Derecho penal...cit., p. 85; WELZEL, Hans. Derecho Penal Alemán...cit., p. 120. 
elemento essencial da autoria, daí referir que a autoria final é a mais ampla forma de domínio final do fato ${ }^{68}$. Com a distinção entre crimes dolosos e culposos já no tipo penal, não poderia haver um conceito único de autor e, por conseguinte, a autoria deveria ser investigada nos delitos dolosos e culposos ${ }^{69}$. WELZEL considerou que autor de um crime culposo seria qualquer indivíduo que, por meio de uma conduta que viola a medida do exigível de cuidado, causasse um resultado típico não desejado ${ }^{70}$. Desse modo, WELZEL restringiu a problemática da autoria, bem como da teoria do domínio do fato, aos crimes dolosos ${ }^{71}$. Assim, a ideia de autoria, na concepção finalista, foi desenvolvida com vista à tripartição conceitual em autoria direta (individual), autoria mediata e coautoria ${ }^{72}$.

Para determinar a autoria nos crimes dolosos, WELZEL partiu da crítica ao critério adotado pelo Tribunal do Reich alemão à época, o da vontade de cometer o fato como próprio (Täterwillen ${ }^{73}$. Dentre as questões levantadas por WELZEL, indagou-se: pode alguém, através de sua mera vontade, tornar um fato qualquer em próprio ${ }^{74}$ ? Respondeu o autor que a teoria subjetiva é absolutamente deficitária e afirmou que decisivo para a determinação da autoria é o fato objetivo

68 WELZEL, Hans. Derecho Penal Alemán...cit., p. 120; ROXIN, Claus. Autoría y dominio del hecho en Derecho penal...cit., p. 85; SILVA, Pablo Rodrigo Alflen da. Teoria do domínio do fato...cit., pp. 87-88.

69 SILVA, Pablo Rodrigo Alflen da. Teoria do domínio do fato...cit., p. 88.

$70 \quad$ Idem, p. 88.

71 WELZEL, Hans. Derecho Penal Alemán...cit., p. 120; SILVA, Pablo Rodrigo Alflen da. Teoria do domínio do fato...cit., p. 88.

72 SILVA, Pablo Rodrigo Alflen da. Teoria do domínio do fato...cit., p. 88.

73 Idem, p. 88.

$74 \quad$ ROXIN, Claus. Autoría y dominio del hecho en Derecho penal...cit., p. 86;

SILVA, Pablo Rodrigo Alflen da. Teoria do domínio do fato...cit., p. 89. 
que realmente tenha sido obra do autor ${ }^{75}$. Entendeu, porém, que este fato objetivo depende de um momento subjetivo, a saber, o domínio final do fato, o qual é mais do que meramente subjetivo, porquanto corresponde àquele que leva à execução, de forma conscientemente final, a sua decisão de vontade ${ }^{76}$.

Assim, para WELZEL, possui o domínio do fato quem é $o$ senhor sobre sua decisão e execução e com isso o senhor sobre seu ato, o qual ele realiza de forma conscientemente final em sua essência e existência ${ }^{77}$. No entanto, considerou que o domínio final do fato (finale Tatherrschaft) não seria o único critério necessário para determinar a autoria. ${ }^{78}$ Isso porque, segundo WELZEL, o conteúdo socialmente relevante da autoria dependeria, ainda, de outros momentos pessoais do autor, a saber, os pressupostos objetivos e o momento subjetivo da autoria, como, por exemplo, a intenção de se apropriar ${ }^{79}$. Segundo o referido autor, somente quando estes pressupostos existissem, o autor possuiria o mais amplo domínio (não meramente final, senão também) socialso.

Portanto, a autoria, para WELZEL, possui ao todo os seguintes pressupostos: (i) pressupostos pessoais, decorrentes da estrutura do tipo: (a) objetivos, tais como a posição especial de dever do autor; e, (b)

\footnotetext{
75 SILVA, Pablo Rodrigo Alflen da. Teoria do domínio do fato...cit., p. 89. 76 Idem, p. 89.

77 WELZEL, Hans. Derecho Penal Alemán...cit., p. 120; SILVA, Pablo Rodrigo Alflen da. Teoria do domínio do fato...cit., p. 89.

78 WELZEL, Hans. Derecho Penal Alemán...cit., p. 121; SILVA, Pablo Rodrigo Alflen da. Teoria do domínio do fato...cit., pp. 89-90.

79 WELZEL, Hans. Derecho Penal Alemán...cit., p. 121; SILVA, Pablo Rodrigo Alflen da. Teoria do domínio do fato...cit., p. 90.

80 WELZEL, Hans. Derecho Penal Alemán...cit., p. 121; ROXIN, Claus. Autoría y dominio del hecho en Derecho penal...cit., p. 88; SILVA, Pablo Rodrigo Alflen da. Teoria do domínio do fato...cit., p. 90.
} 
subjetivos, tais como intenções especiais, tendências ou tipos de sentimentos; e, (ii) pressuposto fático, o domínio do fato ${ }^{81}$.

$\mathrm{Na}$ concepção de WELZEL, a autoria direta consistiria na realização direta, voluntária e conscientemente final do fato por quem, tendo preenchido os pressupostos pessoais objetivos e subjetivos exigidos pelo tipo, possui o domínio pleno sobre a sua decisão e execução ${ }^{82}$.

Disse WELZEL que a coautoria é a própria autoria ${ }^{83}$, cuja peculiaridade consiste em que o domínio final do fato sobre a conduta delitiva encontra-se não com um indivíduo, mas com vários conjuntamente ${ }^{84}$. A coautoria, dessa forma, é caracterizada pela realização dividida entre muitas pessoas dos atos parciais de uma decisão de ação levada a cabo por todas elas conjuntamente e, portanto, o domínio do fato está com todos conjuntamente ${ }^{85}$. Logo, a coautoria nada mais seria do que uma variedade de autores individuais, uma vez que cada coautor seria por si mesmo em parte autor imediato e em parte mediato do fato integral ${ }^{86}$. Assim, WELZEL considerou que somente se poderia falar em coautoria com o preenchimento dos seguintes pressupostos: (i) decisão conjunta do fato ${ }^{87}$; e, (ii) execução

81 WELZEL, Hans. Derecho Penal Alemán...cit., p. 121; SILVA, Pablo Rodrigo Alflen da. Teoria do domínio do fato...cit., p. 90.

82 SILVA, Pablo Rodrigo Alflen da. Teoria do domínio do fato...cit., p. 91.

83 WELZEL, Hans. Derecho Penal Alemán...cit., p. 129.

84 WELZEL, Hans. Derecho Penal Alemán...cit., p. 129; SILVA, Pablo

Rodrigo Alflen da. Teoria do domínio do fato...cit., p. 91.

$85 \quad$ WELZEL, Hans. Derecho Penal Alemán....cit., p. 129; SILVA, Pablo

Rodrigo Alflen da. Teoria do domínio do fato...cit., p. 91.

86 SILVA, Pablo Rodrigo Alflen da. Teoria do domínio do fato...cit., pp. 91-

92.

87 WELZEL, Hans. Derecho Penal Alemán...cit., p. 129; SILVA, Pablo

Rodrigo Alflen da. Teoria do domínio do fato...cit., pp. 92-93. 
conjunta do fato ${ }^{88}$.

Para WELZEL, a autoria mediata consubstancia-se na ideia de domínio final do fato por quem se encontra por trás do instrumento, sendo que este último, em hipótese alguma, pode possuir o domínio pleno do fato, caso contrário, aquele que se encontra por trás será mero indutor ou instigador ${ }^{89}$.

Atribui-se, portanto, a WELZEL, a primeira construção melhor elaborada de um critério objetivo-material - formulado à raiz de sua teoria finalista da ação - de um critério de domínio final do fato, sustentando que a par de requisitos pessoais (as posições especiais de dever que eventualmente o autor possua e os elementos subjetivos especiais do injusto), a autoria deveria exigir como requisito típico o domínio final, ou seja, que o autor seja dono e senhor do fato, enquanto realiza sua decisão de vontade com sentido ${ }^{90}$.

É bem verdade que o critério resulta mais vago e permeável a interpretações do que o objetivo-formal, porém, é igualmente verdade que se aproxima mais do justo, já que quem dá a última palavra sobre o delito é quem pode, definitivamente, ser considerado autor ${ }^{91}$.

Quiçá por causa disso, a ideia central de domínio do fato, também chamada de teoria objetiva material ou teoria objetivosubjetiva, recebeu ampla acolhida na doutrina em geral, a ponto de se tornar francamente dominante, ainda que, justamente por cuidar-se de um conceito aberto, tenha significado igualmente uma abertura importante para a inserção de diferenças importantes entre as teses que

88

WELZEL, Hans. Derecho Penal Alemán...cit., p. 130; SILVA, Pablo Rodrigo Alflen da. Teoria do domínio do fato...cit., pp. 92-93.

89 WELZEL, Hans. Derecho Penal Alemán...cit., p. 122; SILVA, Pablo Rodrigo Alflen da. Teoria do domínio do fato...cit., p. 94.

$90 \quad$ BUSATO, Paulo César. Direito Penal...cit., p. 676.

$91 \quad$ Idem, p. 676. 
trataram do tema ${ }^{92}$.

A ideia geral da teoria do domínio do fato é a de que o autor só pode ser identificado através do critério do domínio do fato, sendo que domina o fato aquele que tem o poder de determinação sobre o crime ${ }^{93}$.

\subsection{ROXIN}

Em sua famosa monografia Täterschaft und Tatherrschaft ${ }^{94}$, ROXIN foi quem mais desenvolveu o tema do domínio do fato ${ }^{95}$ como fundamento da identificação do autor, abrindo muito mais a discussão sobre o tema e desenvolvendo o que, em WELZEL, era apenas esboçado ${ }^{96}$.

ROXIN entende que os critérios objetivos e subjetivos previamente apresentados não são suficientes para a identificação do autor e do partícipe ${ }^{97}$, devendo ser sintetizados em torno de uma concepção que acrescenta outros elementos. O centro de onde parte a teoria é o controle à respeito da realização do crime ${ }^{98}$.

Daí, o ponto de partida do pensamento de ROXIN é a ideia de que o autor é a figura central do acontecer típicos9; a figura-chave do

$\begin{array}{ll}92 & \text { Idem, p. } 676 . \\ 93 & \text { Idem, p. } 677 . \\ 94 & \text { ROXIN, Claus. Täterschaft und Tatherrschaft. München: C.H. Beck, } 1994 .\end{array}$ No texto é utilizada a 7a edição, traduzida para o espanhol: Autoria y domínio del hecho en Derecho penal...cit..

95 SILVA, Pablo Rodrigo Alflen da. Teoria do domínio do fato...cit., p. 104.

$96 \quad$ BUSATO, Paulo César. Direito Penal...cit., p. 677.

97 SILVA, Pablo Rodrigo Alflen da. Teoria do domínio do fato...cit., p. 105.

$98 \quad$ BUSATO, Paulo César. Direito Penal, Parte Geral. 3 ed. São Paulo: Atlas, 2017, p. 677.

99 GRECO, Luís, LEITE, Alaor. O que é e o que não é a teoria do domínio do fat...cit., p. 24. 
acontecimento mediado pela conduta ${ }^{100}$. Essa ideia reitora retém pretensão de validade geral, e se expressa pelo domínio do fato, pela violação de um dever especial ou pelo elemento típico que exige a prática da conduta com as próprias mãos ${ }^{101}$. O domínio do fato é, assim, uma das expressões da ideia de que autor de um delito é sempre a figura central do acontecer típico ${ }^{102}$.

Autor, para essa teoria, é quem domina a realização do fato típico, determina quando, onde, como e se ocorrerá o delito. Enfim, é quem tem o poder de decisão sobre o fato, quer seja porque o realiza, no todo ou em parte, quer porque se utiliza de outrem como instrumento de sua realização, no dizer de JESCHECK, quem governa o curso do fato ${ }^{103}$.

Acontece que o controle sobre o curso do fato não é um conceito fechado ${ }^{104}$, comportando variadas interpretações, o que é reconhecido pela doutrina ${ }^{105}$ como sendo, ao mesmo tempo, o motivo igualmente do êxito e dos problemas de que padece essa teoria.

De qualquer modo, com vistas a uma breve explicação a respeito da teoria, toma-se por base o posicionamento de ROXIN a respeito da mencionada teoria ${ }^{106}$.

Para ROXIN, o que difere essencialmente autor e partícipe é que o autor tem controle sobre a realização do delito, é aquele que

100 SILVA, Pablo Rodrigo Alflen da. Teoria do domínio do fato. São Paulo:

Saraiva, 2014, p. 110.

$101 \quad$ Idem, p. 25.

$102 \quad$ Idem, p. 25.

103 BUSATO, Paulo César. Direito Penal...cit., p. 677.

104 ROXIN, Claus. Autoría y dominio del hecho en Derecho penal...cit., pp.

141-145.

105 SILVA, Pablo Rodrigo Alflen da. Teoria do domínio do fato...cit., pp. 107108. 
pode decidir a respeito dos aspectos essenciais para a produção do resultado, é "a figura central do concreto êxito da ação", circunstância que falta ao partícipe. Importa ressaltar que o próprio ROXIN entende que a teoria do domínio do fato, embora seja de crucial importância para a identificação da autoria na maioria dos crimes, não pode ser aplicada indistintamente ${ }^{107}$.

ROXIN faz um recorte, sustentando que os chamados crimes de domínio (comissivos dolosos) têm a autoria identificada pela teoria do domínio do fato, enquanto que nos chamados delitos de infração de dever (Pflichtdelikte), essa identificação deve dar-se de outra forma. A chamada teoria dos delitos de infração de um dever (Theorie der Pflichtdelikte) igualmente é tratada na obra Täterschaft und Tatherrschaft ${ }^{108}$.

De modo geral, no padrão regular de práticas delitivas - a saber, os crimes comissivos dolosos - o legislador faz no tipo uma completa descrição da conduta proibida, o que faz com que o autor seja identificado como a figura que domina a realização do feito. Aqui, a autoria seria explicada pela teoria do domínio do fato ${ }^{109}$.

O domínio de tal realização não é meramente um controle da causalidade, mas sim um domínio em sentido normativo, relacionado aos critérios de imputação ${ }^{110}$. E o domínio do fato como expressão da ideia reitora da figura central do acontecer típico manifesta-se, por sua vez, de três formas concretas: (i) o domínio da ação; (ii) o domínio da vontade; e, (iii) o domínio funcional do fato.

Assim, dentro de uma ideia geral de domínio do fato, estão

ROXIN, Claus. Autoría y dominio del hecho en Derecho penal...cit., p.

385.

Idem, pp. 385 e ss.

109 BUSATO, Paulo César. Direito Penal...cit., p. 678.

$110 \quad$ Idem, p. 678. 
incluídas todas as formas de autoria, a saber: (i) a autoria imediata (= direta), onde o sujeito que realiza de mão própria ${ }^{111}$, direta $\mathrm{e}$ imediatamente, o delito tem o domínio da ação, pois efetiva a realização jurídica do delito diretamente; (ii) a autoria mediata, quando coage ou induz a erro um terceiro que executa o crime, ou quando possui o domínio de uma organização verticalmente estruturada e dissociada da ordem jurídica ${ }^{112}$, onde o sujeito, conquanto não realize pessoalmente o núcleo do tipo, possui o domínio da vontade, valendo-se de terceiro como seu instrumento, logrando impor sua própria pretensão a despeito do que queira aquele que é instrumentalizado; e, (iii) finalmente, a coautoria, na qual coautor é quem, no marco de um plano comum, dá, juntamente com outra pessoa, uma contribuição relevante à realização do fato, surgindo, como consequência jurídica, uma imputação recíproca ${ }^{113}$, onde o repartir de tarefas entre os coautores traduz um domínio funcional do fato, traduzido pelo cumprimento de funções que são distribuídas entre os coautores ${ }^{114}$.

Acentue-se, como bem pontua SILVA ${ }^{115}$, que a ideia de

111

ROXIN, Claus. Autoría y dominio del hecho en Derecho penal...citm, p. 569; GRECO, Luís, LEITE, Alaor. O que é e o que não é a teoria do domínio do fato...cit., p. 44.

112 ROXIN, Claus. Autoría y dominio del hecho en Derecho penal...cit., p. 569; GRECO, Luís, LEITE, Alaor. O que é e o que não é a teoria do domínio do fato...cit., p. 44.

113 ROXIN, Claus. Autoría y dominio del hecho en Derecho penal...cit., p. 570; GRECO, Luís, LEITE, Alaor. O que é e o que não é a teoria do domínio do fato...cit., p. 44.

114 ROXIN, Claus. Autoría y dominio del hecho en Derecho penal...cit., p. 570; BUSATO, Paulo César. Direito Penal...cit., p. 678; SILVA, Pablo Rodrigo Alflen da. Teoria do domínio do fato...cit., p. 111.

SILVA, Pablo Rodrigo Alflen da. Teoria do domínio do fato...cit., p. 119. 
domínio funcional é desenvolvida por ROXIN com o propósito de demonstrar que o domínio do fato é determinante para a coautoria, e isso em oposição à opinião de SCHRÖDER de que cada coautor domina apenas sua respectiva parte, mas não o acontecimento integral. A coautoria, para ROXIN, consiste na realização do tipo por meio da execução pela divisão de trabalhos, ou seja, no domínio conjunto do fato ${ }^{116}$. O coautor assume uma tarefa, que é essencial para realização do fato planejado e que lhe possibilita, por meio de sua parte no fato, o domínio do acontecimento integral ${ }^{117}$. ROXIN, então, extrai três pressupostos para a coautoria: (i) a existência de um planejamento conjunto do fato, visto que a divisão dos trabalhos pressupõe o cometimento conjunto; (ii) a execução conjunta do fato, não sendo suficiente uma participação na preparação; e, (iii) a prática de uma contribuição essencial à etapa da execução ${ }^{118}$.

A mais importante contribuição da tese de ROXIN foi inaugurar um caminho mais lúcido para a análise dos casos de distribuição de carga de responsabilidade em aparatos de poder organizados. O tema tem constantemente dividido a doutrina a partir da análise do caso Eichmann, por ROXIN ${ }^{119}$, no qual o autor apresenta sua tese favorável ao reconhecimento de um autor detrás do autor, em defesa da aplicação da figura da coautoria às situações de realização do crime no âmbito de uma organização. Os casos de existência de um ente coletivo que se estrutura e instrumentaliza um determinado agente executor do crime são amplos e variáveis, espraiando-se, a partir de casos como o caso Eichmann ou o caso dos atiradores do muro

\footnotetext{
$116 \quad$ Idem, p. 119.

117 Idem, p. 119.

118 Idem, p. 120.

119 ROXIN, Claus. Straftaten im Rahmen organisatorischer Machtapparate.

In: Goltdammer's Archiv für Strafrecht, 1963, pp. 193-207.
} 
de Berlim (Mauerschutzen), até as situações mais corriqueiras, frequentemente encontradas no âmbito empresarial. Cita-se, por oportuno, os casos paradigma e os três critérios de ROXIN. Parte da doutrina não concorda com o terceiro critério de funcionamento às margens do direito, e acaba incluindo as questões empresariais ${ }^{120}$.

No posicionamento mais atual de ROXIN ${ }^{121}$, quatro elementos são caracterizadores da situação capaz de deixar entrever a figura do autor por trás do autor ou do homem de trás, como ficou conhecida na doutrina: (i) o poder de mando de quem tem possibilidade de distribuir as ordens; (ii) a fungibilidade do autor imediato; (iii) a alta disposição para a realização do fato por parte do executor; e, (iv) o aparato de poder organizado estar afastado do direito ${ }^{122}$.

O último elemento é questionado pela doutrina. A um, pelos próprios exemplos utilizados por ROXIN, a saber: o caso dos atiradores do Muro de Berlim. O que é questionável, dentro da posição deles, não é estarem ou não ajustados ao direito, pois, na verdade, estão cumprindo perfeitamente as ordens que sua organização jurídica determina ainda que estas sejam claramente injustas. $\mathrm{O}$ mesmo podese dizer do caso Eichmann. A dois, porque o critério é artificial e não corresponde à realidade criminológica. Ele visa, tão somente, apartar do âmbito da discussão sobre o reconhecimento da autoria a figura da empresa que, não obstante seja evidentemente constituída de uma forma diferente, por exemplo, das máfias ou organizações criminosas, em determinado momento, pode perfeitamente organizar-se e se estruturar em torno da realização de crimes ${ }^{123}$.

Por tal razão, entendemos que a responsabilidade em aparatos

120 BUSATO, Paulo César. Direito Penal...cit., p. 683.

121 ROXIN, Claus. Organisationsherrschaft als...cit., p. 1 e ss.

122 BUSATO, Paulo César. Direito Penal...cit., pp. 683-684.

123 Idem, p. 684. 
de poder organizados admite a figura do autor por trás do autor independentemente de que o fato incriminado se desenvolva em um aparato que atue à margem do direito. Isso inclui, sem dúvida, o âmbito das empresas. Basta que haja os outros três elementos para a caracterização dessa responsabilidade. Vale dizer: o domínio da organização por parte de quem deu a ordem, a fungibilidade do executor e a colocação deste em um ambiente coletivo que criminologicamente protege sua atitude de execução, tornando-o mais propenso à realização do fato ${ }^{124}$.

\subsection{PANORAMA ATUAL. DA TEORIA A UMA PRÁTICA NEM SEMPRE FELIZ.}

Na última década, a teoria do domínio do fato, nos termos de ROTSCH, "deu um salto da teoria para a prática"125. Com isso, a teoria do domínio do fato estabeleceu-se, definitivamente, como instrumento viável para a identificação de responsabilidade pela autoria $^{126}$.

Cita-se, brevemente, dois casos latino-americanos em que a teoria do domínio do fato foi utilizada por Cortes Supremas. No caso peruano, a decisão foi estabelecida em termos científicos. No caso brasileiro, em termos ilegítimos.

$124 \quad$ Idem, p. 685.

125 ROTSCH, Thomas. De Eichmann hasta Fujimori. Sobre la recepción del dominio de la organización después de la sentencia de la Sala Penal Especial de la Corte Suprema de Perú. In: AMBOS, Kai, MEINI, Iván. La autoría mediata: el caso Fujimori. Lima: ARA Editores, 2010, p. 41. 
No caso Fujimori ${ }^{127}$, julgado pela Corte Suprema peruana, os juízes fundamentaram a culpabilidade de Fujimori como autor mediato com grande detalhe e mediante o estudo da literatura, nacional e estrangeira, em um nível que satisfaz amplamente as exigências científicas ${ }^{128}$.

ROXIN afirmou que essa decisão foi um feliz exemplo da ciência jurídico-penal internacional, que não representa apenas uma espécie de estudo de direito comparado à moda antiga, mas sim o anseio de desenvolver regras supranacionalmente válidas para casos que podem ocorrer em qualquer lugar do mundo ${ }^{129}$.

A decisão fundamentou-se na última versão da autoria mediata por domínio da organização desenvolvida por ROXIN ${ }^{130}$. Nos trabalhos mais recentes, ROXIN enunciou quatro fatores que permitem fundamentar o domínio do fato do homem de trás em organizações delitivas: (i) o poder de emitir ordens que possui o homem de trás; (ii) a dissociação da ordem jurídica do aparato de poder à disposição do emissor das ordens; (iii) a fungibilidade do executor imediato; e, (iv) a disposição essencialmente alta para o fato do executor ${ }^{131}$. Esses quatro critérios ocuparam lugar de destaque entre as exigências da Corte peruana, tiveram sua justificação material por ela afirmada e, por fim,

127 Cf. por todos: AMBOS, Kai, MEINI, Iván. La autoría mediata: el caso Fujimori. Lima: ARA Editores, 2010.

128 ROTSCH, Thomas. De Eichmann hasta Fujimori...cit., p. 41; também: ROXIN, Claus. Observações sobre a decisão da Corte Suprema Peruana no Caso Fujimori. In: ROXIN, Claus. Novos estudos de direito penal. Trad. Alaor Leite. São Paulo: Marcial Pons, 2014, p. 182.

129 ROXIN, Claus. Observações sobre a decisão da Corte Suprema Peruana...cit., pp. 182-183.

$130 \quad$ Idem, 183.

$131 \quad$ Idem, 183. 
foram considerados devidamente realizados no caso em questão ${ }^{132}$.

Por fim, disse ROXIN que o significado histórico da decisão possui dois aspectos: um político, outro jurídico-penal. No sentido político, a decisão demonstrou que é possível dar tratamento jurídico a um fato punível cometido por um ditador deposto no interior de um irrepreensível processo em conformidade ao Estado de Direito, renunciando, assim, à bárbara pena de morte. No sentido jurídico, o julgamento demonstra quão frutífera pode ser uma ciência jurídicopenal internacional, que, além de analisar de forma completa a jurisprudência e doutrina do próprio país, conquista novos argumentos ao levar cuidadosamente em consideração a literatura estrangeira, que é capaz de produzir consenso internacionalmente ${ }^{133}$.

No caso Mensalão (AP 470/STF) ${ }^{134}$, julgado pela Corte Suprema brasileira, os Ministros fizeram um esforço no sentido de buscar legitimidade científica para os respectivos votos, não se preocupando com as precisões técnicas contidas na formulação teórica de ROXIN ${ }^{135}$. Nos termos da crítica de LEITE, em suma, "a teoria do domínio do fato, tal como foi concebida originariamente na ciência jurídica, nada tem a ver com a decisão da $A P 470$ "136. Os resultados da análise de LEITE acerca da decisão da AP 470/STF são os seguintes: (i) a impossibilidade de que se considere essa decisão como um precedente modelo; e, (ii) a

\footnotetext{
$132 \quad$ Idem, p. 183.

133 Idem, p. 190.

134 Cf., por todos: LEITE, Alaor. Domínio do fato, domínio da organização e responsabilidade penal por fatos de terceiros. Os conceitos de autor e partícipe na AP 470 do Supremo Tribunal Federal. In: GRECO, Luís (et alii) Autoria como domínio do fato: estudos introdutórios sobre o concurso de pessoas no direito penal brasileiro. São Paulo: Marcial Pons, 2014, pp. 123-168.

135 LEITE, Alaor. Domínio do fato, domínio da organização e responsabilidade penal...cit., p. 166.
}

$136 \quad$ Idem, p. 168. 
verdadeira razão para o recurso à teoria do domínio do fato não foi a necessidade de distinguir entre autor e partícipe no direito penal, mas a necessidade de fundamentar a responsabilidade daqueles que ocupam posição de comando, criando uma espécie de autoria por domínio da posição, que nada tem a ver com a teoria do domínio do fato ${ }^{137}$.

\subsection{CRÍTICAS}

As críticas existentes a esse modelo, em geral, são dirigidas à proposta inicial, de WELZEL, e não têm relação com o conceito de domínio do fato, mas sim com a ideia de domínio final do fato. Ou seja, estão direcionadas ao evidente fracasso da proposta de uma teoria da ação finalista. Assim, critica-se a finalidade na culpa inconsciente e também no caso dos delitos omissivos. Os próprios defensores desse ponto de vista entendem necessário o seu complemento por outros critérios em casos limítrofes ${ }^{138}$.

Porém, a proposta de ROXIN também não é imune a críticas.

Segundo SILVA ${ }^{139}$, dos três pressupostos apresentados por ROXIN, o único que resta incólume a critica, é o primeiro. SILVA atribui a MUÑOZ CONDE - e concorda com ele - que o requisito da coexecução não é nada mais do que consequência de uma teoria objetivo-formal, a qual, de modo geral, tem se mostrado insuficiente para explicar o conceito de autoria e mais ainda para explicar o conceito de coautoria, sobretudo naqueles âmbitos da criminalidade, nos quais tão importante ou mais que a execução mesma são outras

\footnotetext{
$137 \quad$ Idem, pp. 167.

138 BUSATO, Paulo César. Direito Penal...cit., pp. 678-679.

139 SILVA, Pablo Rodrigo Alflen da. Teoria do domínio do fato...cit., pp. 122 e 123.
} 
condutas de decisão ou organização relacionadas com ela ${ }^{140}$.Com relação ao pressuposto da relevância da contribuição na etapa da execução, SILVA constata que ROXIN não esclarece o que se deve considerar como relevante, tratando-se de um critério puramente causal $^{141}$.

GÓRRIZ ROYO afirma que o critério do domínio de fato de ROXIN não pode ser extraído de um conceito geral de autor. Segundo ela, são frequentes as alusões ao conceito geral de figura central ou diretamente ao conceito geral de domínio do fato. E, ainda quando não tenha por propósito inicial, nem finalmente logre, articular um conceito ou critério universal para definir a autoria em toda classe de delitos, como a doutrina majoritária interpreta, sem dúvida o domínio do fato constitui um critério com vocação de generalidade para determinar o autor, ao menos, a respeito de certos delitos dolosos de ação. Ocorre que a proposta de ROXIN resulta mais limitada e modesta do que a sua pretensão, já que tampouco consegue configurar um critério geral para delimitar a autoria nos delitos de domínio. A um, porque o domínio do fato é um critério por si só insuficiente para determinar quando estamos diante de um sujeito que devemos atribuir um comportamento relevante a título de autor. A dois, porque tampouco chega a explicar, conforme este critério, a intervenção delitiva em casos de delitos omissivos nem nos casos de delitos imprudentes ${ }^{142}$.

\subsection{IMPORTÂNCIA REMANESCENTE}

\footnotetext{
$140 \quad$ Idem, p. 122.

141 Idem, p. 123.

142 GÓRRIZ ROYO, Elena María. El concepto de autor en Derecho penal.

Valencia: Tirant lo Blanch, 2008, pp. 343-344.
} 
Embora as críticas apresentadas sejam pertinentes, não se pode negar, segundo advertem GRECO/LEITE, que a doutrina aderiu amplamente à teoria do domínio do fato como ideia capaz de indicar contornos mais concretos para a distinção entre autor e partícipe ${ }^{143}$.

Para os referidos autores, as ideias contidas na teoria do domínio do fato estão no centro da discussão desde os anos que se seguiram à sua enunciação até os dias de hoje, representando uma evolução na teoria do concurso de pessoas, principalmente, devido aos seguintes pontos: (i) a sistematização das formas de autoria; (ii) a diferenciação entre as diversas espécies de autoria mediata, segundo os seus fundamentos; (iii) a clarificação da estrutura da coautoria, como atuar conjunto fundado em divisão de tarefas ou funções; (iv) a teoria dos delitos de dever; e, (v) a delitos de mão própria ${ }^{144}$.

A mais notória consequência da construção de ROXIN é a figura da autoria mediata por meio de aparatos organizados de poder, que depois de tornar-se doutrina majoritária, foi admitida não apenas pela jurisprudência alemã, como também pela jurisprudências de outros países, como da Argentina, do Peru, e do Brasil (mesmo que impropriamente) ${ }^{145}$.

Ademais, a solução apresentada por ROXIN, dividindo entre os delitos de domínio e os delitos de dever, aplicando a teoria do domínio do fato aos primeiros e aplicando a camada teoria dos delitos de violação de dever, parece ter dado uma solução bastante satisfatória ao tema, recortando o âmbito de aplicação da teoria do domínio do fato e, como consequência disso, reforçando a conclusão pelo acerto de seus

143 GRECO, Luís, LEITE, Alaor. O que é e o que não é a teoria do domínio do fato...cit., p. 35 .

$144 \quad$ Idem, p. 35.

$145 \quad$ Idem, p. 36. 
resultados ${ }^{146}$.

Para ROXIN, a teoria do domínio do fato deve ceder espaço nos casos dos chamados delitos de violação de um dever - como é o caso dos delitos omissivos e os especiais ou próprios, onde a fonte de responsabilidade não é a atuação em si, mas sim o dever a que estão obrigados os autores -, para uma teoria dos delitos de dever. Ou seja, não se explica a responsabilidade a partir do controle que alguém exerce a respeito da realização do fato, mas sim em função do dever de cuidado a que o agente está obrigado ${ }^{147}$.

Nesse sentido, por exemplo, não se pode sustentar que alguém que se omite controla a produção do resultado de alguma forma, pois de uma omissão não poderá brotar essa classe de controle. Por outro lado, é certo que a responsabilidade, na omissão, deriva da presença de um dever e que quem tem o dever de agir e não age é o responsável principal pela produção do resultado delitivo. Assim, os delitos omissivos - próprios e impróprios - são delitos cuja essência da imputação reside não no domínio do fato, mas na violação do dever ${ }^{148}$.

O mesmo se pode dizer dos casos dos crimes especiais ou próprios - aqueles que exigem, do sujeito ativo, alguma qualidade ou condição especial -, onde, existindo uma pluralidade de agentes, o autor sempre será o intraneus, ou seja, aquele que está incluído no círculo de autores delimitados normativamente pelo tipo. Desse modo, somente as pessoas que reúnam a qualidade específica mencionada pelo tipo estão em condições de serem identificadas como autoras ${ }^{149}$.

\footnotetext{
146 BUSATO, Paulo César. Direito Penal...cit., p. 679.

385.

147 ROXIN, Claus. Autoría y dominio del hecho en Derecho penal...cit., p. 


\section{A TEORIA DO DOMÍNIO DO FATO É APLICÁVEL PARA A INTERPRETAÇÃO DO CONCURSO DE PESSOAS NO CP/84?}

Dada a situação atual da teoria do domínio do fato no concurso de pessoas, quer seja pelo estado da discussão teórica, seja pelo (por vezes) malfadado emprego que dela se fez em termos práticos no Brasil, está bastante claro que se reclama uma maior discussão em torno de seus postulados, de sua utilidade e da sua relevância para o Direito penal brasileiro.

Uma parte mais lúcida da doutrina ${ }^{150}$ já se deu conta deste estado de coisas e começa a se posicionar a respeito do tema.

Neste sentido, a proposta deste artigo é somar-se ao esforço de discutir os postulados teóricos da teoria do domínio do fato à luz da estrutura normativa do Código Penal brasileiro, sempre com o com o óculo posto sobre a praxis forense, visando determinar se há ou não alguma utilidade da teoria do domínio do fato para o sistema de imputação existente no Brasil.

\subsection{OS ARGUMENTOS DE QUEM ACHA QUE NÃO}

DOTTI defende que as disposições do art. 29, capute parágrafos do Código Penal brasileiro não se harmonizam com a teoria do domínio do fato, porque (i) a faculdade judicial para reduzir a pena se a participação for de menor importância não satisfaz a exigência dogmática de que a participação tenha uma tipicidade autônoma ${ }^{151}$; e, (ii) enquanto o art. 29 do Código Penal adota um sistema unitário, a 
teoria do domínio do fato está ancorada em um sistema diferenciador ${ }^{152}$.

SILVA assinala que não há como transpor a teoria do domínio do fato de ROXIN ao plano brasileiro, devido à sua absoluta incompatibilidade com a ordem jurídica vigente e com a opção do legislador brasileiro por um sistema unitário funcional ${ }^{153}$. Segundo o autor, a impossibilidade se dá por duas razões: (i) porque o próprio ROXIN não só rechaça categoricamente a adoção de um sistema unitário, como esclarece que desenvolve sua teoria sobre o pilar do sistema diferenciador; e, (ii) porque a concepção de domínio do fato (tanto de WELZEL quanto de ROXIN) está assentada no absoluto rechaço a premissas causais-naturalistas, as quais, diferentemente, são o pilar de sustentação do sistema unitário ${ }^{154}$.

\subsection{POR QUÊ ACHAMOS QUE SIM}

Inicia-se o tópico final parafraseando BATISTA: "o art. 29 drasticamente estipulou que 'quem, de qualquer modo, concorre para o crime, incide nas penas a este cominadas'. Não nos informou, todavia, como é que ('de qualquer modo') se concorre para o crime. Verificada a insuficiência de um puro critério causal para solucionar essa questão (concorrer para o crime é diferente de contribuir causalmente para o resultado); verificado que equiparar 'qualquer modo', para alem de violar o princípio constitucional da reserva legal, significa operar com uma causalidade inútil (extratípica), só nos resta a tentativa de, a partir dos dispositivos do código e de seus princípios

152 Idem, pp. 17-18.

153 SILVA, Pablo Rodrigo Alflen da. Teoria do domínio do fato...cit., p. 170.

$154 \quad$ Idem, p. 169. 
fundamentais, empreender uma reconstrução dogmática extremamente dificultada pela pobreza da lei"155.

Note-se que a lucidez de Nilo BATISTA na abordagem da questão, firma claramente um caminho: é preciso explicar as lacunas geradas pelas disposições normativas do Código. E elas não se restringem à vaga referência à contribuição "de qualquer modo" para o crime, mas também se insere na mesma inconsistência a referência à "medida da culpabilidade" para o padrão de mensuração da relevância da contribuição para o concurso e à "participação de menor importância", referida no art. $29 \S 1^{\circ}$ do CP. E a exploração destas lacunas normativas certamente deve dar-se a partir do plano teórico.

É preciso construir, dogmaticamente, critérios válidos para a interpretação de quando a medida da culpabilidade é tal que deve-se considerar a contribuição menos importante, merecedora de uma redução da pena; deve-se estabelecer concretamente segundo que critérios podemos chamar uma contribuição de "participação de menor importância" e é fundamental definir critérios de identificação do que pode ser considerado "ajuste, determinação ou instigação e auxílio", para permitir a limitação da responsabilidade pela acessoriedade referida no art. 31 do CP.

Como se nota, a questão é essencialmente prática. O socorro hermenêutico, porém, provém claramente do desenvolvimento dogmático.

É possível admitir que existem dois sistemas consolidados. Correto. Não há como ser unitário e diferenciador ao mesmo tempo. Perfeito. Agora, quem é que disse que o nosso código é sistemático

155 BATISTA, Nilo. Concurso de agentes: uma investigação sobre os problemas da autoria e da participação no Direito Penal brasileiro. 4 ed. Rio de Janeiro: Lumen Juris, 2008, pp. 54-55. 
quando trata do concurso de pessoas? Quando ele estabelece concessões, ele deixa de ser sistemático e passa a ser assistemático. $\mathrm{O}$ Código possui um conjunto de normas que não se ajusta concretamente nem a um sistema diferenciador, nem a um sistema unitário. De qualquer sorte, são estas as normas que existem e que cabe interpretar. Não é possível negar a existência das regras ou ignorá-las quando se pretende resolver os problemas concretos de concurso de pessoas.

O fato de ser o código assistemático não obriga o intérprete a desprezar completamente os critérios dogmáticos que são oferecidos pelos sistemas. Ou seja, os critérios interpretativos contidos nas estruturas dogmáticas não são institutos sacrossantos que só podem ser tocados - ou, neste caso, utilizados - por aqueles que curvarem-se às suas exigências de coerência intrassistemática. Sustentar isso é colocar no pedestal o sistema mediante o desprezo de seu sentido prático.

O conjunto de regras do Código Penal brasileiro é misto ou temperado ainda que não possa ser chamado de sistema, já que não existe um sistema misto. As regras não podem desprezadas como tais, simplesmente porque considerar-se vedado utilizar um modelo teórico fechado. Gostemos ou não, o nosso legislador fez essa diferenciação. Vamos ignorá-lo porque as regras não corresponde ao sistema unitário? A regra está lá. E deve ser obedecida.

E o nosso legislador quebrou o sistema unitário. Não existe um sistema unitário puro no Código Penal brasileiro. Como aponta SILVA, o legislador brasileiro deixou claro que o sistema unitário não é incompatível com a diferenciação entre as modalidades de autoria e participação ${ }^{156}$. E, ao obrigar aos operadores do direito a realizarem a diferenciação, convoca-os a explicitar os argumentos e fundamentos 
pelos quais se procede tal distinção. Queiramos ou não, é preciso estabelecer, na prática, o que identifica autores e partícipes. O fato é que Código Penal brasileiro, nos artigos 29-31 não impede o uso dos critérios da teoria do domínio do fato para delimitar o conceito de autor e de partícipe, como igualmente não impede que nenhum outro tipo de critério seja utilizado para este fim. $\mathrm{Na}$ verdade, bem ao contrário, ele exige a diferenciação.

Como assinalam GRECO/LEITE, a teoria do domínio do fato, como toda teoria jurídica deve ser, direta ou indiretamente, é uma resposta a um problema concreto. E o problema que a teoria do domínio do fato se propõe a resolver é o de distinguir autor e partícipe $^{157}$.

Se o conjunto de normas contido no Código Penal brasileiro obriga a tal diferenciação, os critérios do domínio do fato, então, vem em socorro e são compatíveis com a interpretação das normas contidas do nosso código. Há uma razão para se utilizar os critérios da teoria do domínio para justificar a fundamentação da autoria e participação. Ao trabalhar com o que temos, não podemos esperar que o legislador altere o código para um sistema harmônico diferenciador ${ }^{158}$, para só

157 GRECO, Luís, LEITE, Alaor. O que é e o que não é a teoria do domínio do fato...cit., p. 22; também: LEITE, Alaor. Domínio do fato ou domínio da posição?...cit., pp. 36-37: "O propósito da teoria do domínio do fato é, a um só tempo, modesto e amplo: É modesto, pois visa apenas a distinguir autores de partícipes, ou seja, a distribuir títulos de contribuição para o delito (...) Ela não decide sobre o se, mas sobre o como da punição".

158 Discordamos, aqui, do posicionamento de LEITE, quando afirma que " $O$ fundamental é que haja uma resoluta decisão em favor da adoção integral de um sistema diferenciador, e não um manejo aleatório de conceitos jurídicos"(LEITE, Alaor. Domínio do fato ou domínio da posição?...cit., p. 43). Isso porque, a interpretação das regras do concurso de pessoas, previstas no Código Penal 
então utilizar tais filtros interpretativos. E, se, os critérios lançados pela teoria do domínio do fato são úteis para estabelecer tais diferenciações, propondo resultados mais justos, simplesmente, não há razão que vede sua utilização.

A questão passa a ser como utilizar os critérios da teoria do domínio de fato de acordo com as regras do nosso código. O fato é que o conjunto de critérios para a distinção de autores e partícipes que apresenta a teoria do domínio do fato, ainda que tenham sido criados em um sistema diferenciador, produzem resultados melhores do que o conjunto de critérios de uma teoria objetivo-formal ou por uma teoria subjetiva, quando aplicados para a interpretação do conjunto de normas do Código Penal brasileiro acerca do concurso de pessoas.

Assinala LEITE que não há óbice para a adoção de um sistema diferenciador já de lege lata. Segundo o referido autor, a teoria do domínio do fato, corretamente compreendida e sem ardilosos disfarces, oferece critérios distintivos aptos a guiar a interpretação judicial ${ }^{159}$. E esse é o ponto do artigo.

Concordamos com tal afirmação. O que se pretende dizer, neste trabalho, é que os dispositivos legais contidos no Código Penal brasileiro (arts. 29-31), sem pensarmos no sistema utilizado pela lei, autorizam, de lege lata, o uso dos critérios pelos quais a teoria do domínio do fato distingue autores de partícipes. Não obstante, de lege ferenda, coubesse ao legislador observar a melhor técnica para elaborar a norma prevendo o critério do domínio do fato de acordo com o sistema diferenciador.

Agora, importa, aqui, exaltar o rendimento que a teoria do

brasileiro, à luz do critério do domínio do fato, independe da adoção do sistema diferenciador pelo legislador.

LEITE, Alaor. Domínio do fato ou domínio da posição?...cit., p. 52. 
domínio do fato pode oferecer ao operador do direito, sem que haja contrariedade ao texto da lei.

No estudo de GRECO/TEIXEIRA, os autores são claros em afirmar que os dispositivos do Código Penal brasileiro, embora apontem para um modelo extensivo e unitário, não são refratários a uma reinterpretação baseada em um modelo restritivo e diferenciador. Mais. Tomados individualmente, alguns permanecem de todo neutros diante dos dois sistemas. Outros, não obstante mais próprios de um sistema unitário, permitem uma reinterpretação progressiva fundada na ideia de legalidade ${ }^{160}$. Concluem, ao final, que, com o apoio de argumentos adicionais baseados na interpretação de determinados dispositivos e com base no princípio da legalidade, é possível falar já de lege lata de um conceito restritivo de autor e da utilização, em tal identificação, dos critérios formulados pela teoria do domínio do fato ${ }^{161}$.

No mesmo sentido, recentemente, GRECO/LEITE afirmaram que, "de fato, existem esforços na doutrina brasileira no sentido de interpretar o direito positivo brasileiro, já de lege lata, no sentido de um sistema diferenciador de autoria e participação. Não há, a nosso ver, nenhum empecilho intransponivel a barrar esses esforços. Afinal, trata-se de uma interpretação construtiva limitadora da punibilidade, que, ademais, encontra apoio na vontade declarada do legislador que reformou a parte geral do CPB em 1984"162.

p. 78.

Idem, p. 80.

162 GRECO, Luís, LEITE, Alaor. A "recepção" das teorias do domínio do fato e do domínio da organização no direito penal econômico brasileiro. Observações sobre as formas de intervenção no delito na Ação Penal 470 do Supremo Tribunal Federal brasileiro (“Caso Mensalão”), ZIS 7-8/2015, p. 389. 
BATISTA também assinala positivamente ao uso da teoria do domínio de acordo com as regras do Direito Penal brasileiro. Diz ele que "sob uma perspectiva generalizante, a distinção autoriaparticipação se aproximará de seu ponto de repouso: os tipos da parte especial. Na apreciação individualizada de cada caso, corresponderá ao juiz verificar quem possuía o domínio do fato (nas suas diferentes formas de exprimir-se) e quem o não possuía, discernindo autores e partícipes. Para o direito penal brasileiro, nenhum obstáculo teórico existe contra a utilização desse critério para os crimes comissivos dolosos" $"$.63.

A teoria do domínio do fato, como teoria, só faz sentido em um sistema diferenciador. Porém, os critérios derivados dessa teoria podem ser empregados em qualquer estrutura normativa, sistemática ou assistemática. Fazer sentido ou não fazer sentido pertence a um conjunto de regras, a um conjunto de critérios. É preciso valorar a participação de cada contribuinte para o delito, de acordo com sua culpabilidade. E, para tanto, precisamos de critérios. Podemos usar o objetivo-formal, subjetivo, etc., e também os critérios da teoria do domínio do fato. Se a teoria do domínio do fato serve para definir o "como" e não o "se" da responsabilização penal, seus critérios são aplicáveis para as regras do Código penal.

Vale dizer, a teoria do domínio do fato, em um sistema unitário puro, em verdade, não se justifica. Isso porque, foi criada em um sistema diferenciador. Porém, os critérios da teoria do domínio fato são de extrema relevância para a estabelecer a distinção autor/partícipe no modelo assistemático do nosso Código Penal.

Portanto, os critérios de diferenciação entre autores e partícipes oferecidos pela a teoria do domínio do fato, desde que conjugados com 
uma teoria de violação de dever específica para os crimes omissivos e os crimes próprios ou especiais, são os que melhor conduzem à identificação de quem pode ser autor e quem deve ser reconhecido como partícipe em um concurso de pessoas para a prática de um crime ${ }^{164}$.

Ademais, convém aduzir que tal proposta resulta perfeitamente compatível com o desenho do Código Penal brasileiro, tudo recomendando sua utilização. Inclusive, porque na complexidade dos aparatos organizados, especialmente da delinquência empresarial, resulta praticamente impossível determinar a autoria sem o socorro a esse critério ${ }^{165}$.

\section{CONCLUSÃO}

Conclui-se, portanto, que o Código Penal brasileiro, em sua reforma da parte geral havida em 1984 ficou a meio caminho entre um sistema unitário e um sistema diferenciador, pois o seu conjunto de normas não foi capaz de propor claramente um sistema diferenciador, porém, ao mesmo tempo, obrigou o intérprete à diferenciar entre os concorrentes de acordo com sua culpabilidade, obrigou a reduzir a pena de um participante do evento, cuja contribuição tenha sido de menor importância e determinou a acessoriedade das atividades consistentes em mero ajuste, determinação, instigação ou auxílio, frente a realização do crime propriamente dito.

Não há alternativa para o intérprete, que não identificar, nos casos de concursos de pessoas quando se está frente a um ajuste, a uma determinação (leia-se, indução), a uma instigação ou a um auxílio (leia- 
se cumplicidade), e quando se está frente a uma verdadeira autoria. Quando uma participação é menos relevante e quando é essencial, e estabelecer, com base nisso, com base no grau de reprovabilidade da contribuição havida (na medida de sua culpabilidade), a pena devida a cada indivíduo.

Assim, parece não haver inconveniente algum para os casos de concursos de pessoas, excetuados os casos de delitos de violação de dever, crimes omissivos e crimes especiais, onde o Código brasileiro tem regras próprias e são pontos recortados da teoria do domínio do fato, que os critérios desenvolvidos por ROXIN sirvam de parâmetro para a interpretação das normas positivas do Direito brasileiro, nominalmente os arts. 29, caput, $29 \S 1^{\circ}$ e 31 do Código penal.

Assim, não há problema algum em sustentar que será instigador, indutor ou cúmplice (para fins do art. 31 do CP) aquele que não possua domínio da ação, domínio da vontade ou domínio funcional, na situação concreta observada, devendo, assim, somente ser responsabilizado na medida em que alguém que possua tais características realize o crime.

Tampouco parece equivocado sustentar, por exemplo, que somente procede a redução de pena do $\S 1^{\circ}$ do art. 29 pelo reconhecimento da reduzida importância da participação do agente, que dar-se-á quando ele não possua domínio da ação, domínio da vontade ou domínio funcional, em face da realização do crime.

Finalmente, pode-se dizer obrigatória a redução da carga penal da pena base - uma vez que a baliza central de sua análise é a culpabilidade, e as responsabilidades dos concorrentes restarão estabelecidas na medida de sua culpabilidade (art. 29, caput do CP) quando o concorrente para um delito não possua domínio da ação, domínio da vontade ou domínio funcional.

Enfim, não existe nenhuma razão para que não possamos 
utilizar tais critérios para resolver os problemas práticos oferecidos pelo Código penal brasileiro acerca de autoria e participação à luz dos critérios da teoria do domínio do fato.

Postura contrária equivale a elevar tais critérios a um patamar sacrossanto e intocável tratando a dogmática com os postulados de ciência, em sentido de ciência natural, dotada de uma verdade intrínseca e convertendo-a em centro gravitacional do sistema penal.

É preciso reduzir a pretensão dos juristas. O direito não é ciência, mas somente uma forma de argumentar ao redor de tópicos ${ }^{166}$. O que se pretende com ele não é mais do que organizar a solução de problemas práticos. A dogmática deve ser funcional para isto e para produzir um mínimo de segurança nas decisões acerca da imputação e nada mais. No momento em que a dogmática, ensimesmada, deixar de promover os resultados mais justos possíveis, será ela, e não as normas que ela pretende interpretar, aquela fadada a desaparecer.

\section{REFERÊNCIAS}

AMBOS, Kai, MEINI, Iván. La autoría mediata: el caso Fujimori. Lima: ARA Editores, 2010.

BATISTA, Nilo. Concurso de agentes. uma investigação sobre os problemas da autoria e da participação no Direito Penal brasileiro. 4 ed. Rio de Janeiro: Lumen Juris, 2008.

BITENCOURT, Cezar Roberto. Tratado de Direito Penal, Parte Geral. Vol. 1. 14 ed. São Paulo: Saraiva, 2009. 
BRANDÃO, Cláudio. Curso de Direito Penal, Parte Geral. Rio de Janeiro: Forense, 2008.

BUSATO, Paulo César. Direito Penal, Parte Geral. 3 ed. São Paulo: Atlas, 2017.

DOTTI, René Ariel. Apresentação. In: LEITE, Alaor. Domínio do fato ou domínio da posição?: autoria e participação no direito penal brasileiro. Curitiba: Centro de Estudos Professor Dotti, 2016. FRAGOSO, Heleno Cláudio. Lições de Direito Penal, Parte Geral. 15 ed. Rio de Janeiro: Forense, 1995.

GALVÃO, Fernando. Direito Penal, Parte Geral. 5 ed. São Paulo: Saraiva, 2013.

GÓRRIZ ROYO, Elena María. El concepto de autor en Derecho penal. Valencia: Tirant lo Blanch, 2008.

GRECO, Luís (et alii) Autoria como domínio do fato: estudos introdutórios sobre o concurso de pessoas no direito penal brasileiro. São Paulo: Marcial Pons, 2014.

, LEITE, Alaor. O que é e o que não é a teoria do domínio do fato. Sobre a distinção entre autor e participe no Direito penal. In: GRECO, Luis (et alii) Autoria como domínio do fato: estudos introdutórios sobre o concurso de pessoas no direito penal brasileiro. São Paulo: Marcial Pons, 2014.

, TEIXEIRA, Adriano. Autoria como realização do tipo: uma introdução à ideia de domínio do fato como o fundamento central da autoria no Direito penal brasileiro. In: GRECO, Luís (et alii) Autoria como domínio do fato: estudos introdutórios sobre o concurso de pessoas no direito penal brasileiro. São Paulo: Marcial Pons, 2014. , LEITE, Alaor. A "recepção" das teorias do domínio do fato e do domínio da organização no direito penal econômico brasileiro. Observações sobre as formas de intervenção no delito na Ação Penal 
470 do Supremo Tribunal Federal brasileiro ("Caso Mensalão"), ZIS 7-8/2015, p. 389.

KANT, Immanuel. Crítica da razão pura. $3^{\mathrm{a}}$ ed., Trad. de Lucimar A. Coghi Anselmi, São Paulo: Ícone, 2011.

LEITE, Alaor. Domínio do fato, domínio da organização e responsabilidade penal por fatos de terceiros. Os conceitos de autor e partícipe na AP 470 do Supremo Tribunal Federal. In: GRECO, Luís (et alii) Autoria como domínio do fato: estudos introdutórios sobre o concurso de pessoas no direito penal brasileiro. São Paulo: Marcial Pons, 2014.

. Domínio do fato ou domínio da posição?: autoria e participação no direito penal brasileiro. Curitiba: Centro de Estudos Professor Dotti, 2016.

MESTIERI, João. Manual de Direito Penal, Parte Geral. Vol. I. Rio de Janeiro: Forense, 2002.

MUÑOZ CONDE, Francisco, GARCÍA ARÁN, Mercedes. Derecho Penal, Parte General. 5 ed. Valencia: Tirant lo Blanch, 2002. ROTSCH, Thomas. De Eichmann hasta Fujimori. Sobre la recepción del dominio de la organización después de la sentencia de la Sala Penal Especial de la Corte Suprema de Perú. In: AMBOS, Kai, MEINI, Iván. La autoría mediata: el caso Fujimori. Lima: ARA Editores, 2010.

ROXIN, Claus. Straftaten im Rahmen organisatorischer Machtapparate. In: Goltdammer's Archiv für Strafrecht, 1963, pp. 193-207.

. Autoría y dominio del hecho en Derecho penal. Trad. Joaquín Cuello Contreras e José Luis Serrano González de Murillo. Madrid: Marcial Pons, 2000. 
. Organisationsherrschaft als eigenständige Form mittelbarer Tätterschaft. In: Schweizerischen Zeitschrift für Strafrecht, n. 125, 2007, p. 1 e ss.

. Observações sobre a decisão da Corte Suprema Peruana no Caso Fujimori. In: ROXIN, Claus. Novos estudos de direito penal. Trad. Alaor Leite. São Paulo: Marcial Pons, 2014.

SANTOS, Juarez Cirino dos. Direito Penal, Parte Geral. 3 ed.

Curitiba: ICPC/Lumen Juris, 2008.

SILVA, Pablo Rodrigo Alflen da. Teoria do domínio do fato. São

Paulo: Saraiva, 2014.

WEBER, Hellmuth von. Lineamientos del Derecho penal alemán.

Trad. de Leonardo G. Brond, Buenos Aires: Ediar, 2008.

WELZEL, Hans. Derecho Penal Alemán. 4 ed. Trad. Juan Bustos Ramírez e Sérgio Yáñez Pérez. Santiago: Editorial Jurídica de Chile, 1997. 